\title{
Meat tenderization using bromelain enzyme extracted from pineapple waste
}

\author{
${ }^{1}$ Woinue, Y., ${ }^{2}$ Chaurasiya, R.S. and ${ }^{3, *}$ Sharma, R. \\ ${ }^{1}$ Department of Life Science, School of Basic Science and Research, Sharda University, Greater Noida, \\ Gautam Buddh Nagar, Uttar Pradesh - 201306, India \\ ${ }^{2}$ String Bio Private Limited, Bangalore, Karnataka - 560073, India \\ ${ }^{3}$ Department of Biotechnology, School of Engineering and Technology, Sharda University, Greater Noida, \\ Gautam Buddh Nagar, Uttar Pradesh - 201306, India
}

\author{
Article history: \\ Received: 21 September 2020 \\ Received in revised form: 20 \\ October 2020 \\ Accepted: 4 March 2021 \\ Available Online: 11 April \\ 2021 \\ Keywords: \\ Bromelain, \\ Enzymatic Treatment, \\ Meat, \\ Proteolysis, \\ Tenderization
}

DOI:

https://doi.org/10.26656/fr.2017.5(2).525

\begin{abstract}
Tenderization is an important method to improve the quality and palatability of meat. In comparison to conventional chemical and physical methods of meat tenderization, enzymatic treatment is more economical and healthy. In the present study proteolytic enzyme bromelain was used for this purpose. Bromelain enzyme was extracted from pineapple, quantified and optimized concentration was used for treating the muscle fibre of meat. Tenderness was measured. $\mathrm{pH}$ and cooking loss were not significantly $(\mathrm{P}>0.05)$ decreased, but water-holding capacity and protein content were significantly $(\mathrm{P}<0.05)$ increased with the concentration and ageing. Duration of marination was optimized and SDS- PAGE electrophoresis was conducted to estimate protein. The results proved that bromelain enzyme is an effective method of tenderization used to improve the quality of meat.
\end{abstract}

\section{Introduction}

Meat is a product from animals such as poultry, sheep and goat, buffalo etc, which is used in processed meat product or kitchen style food. The desirability of meat is based on the nutritional, compositional quality and palatability factors. Meat quality is defined by those traits the consumer perceives as desirable which include both visual and sensory traits and credence traits of safety, health and more intangible traits such as 'clean' and 'green' or welfare status of the production system (Becker, 2000). Important visual traits of raw meat include; colour and texture of the meat, fat colour, amount and distribution of fat as well as the absence of excess water (purge). Consumer satisfaction is largely determined by how tender the cooked meat is as well as its flavour/odour and juiciness (Glitsch, 2000). The implementation of a management system for improving meat tenderness and quality requires the application of process control to prevent quality shortfalls, verification of compliance to specifications for tenderness/quality, and identification of methods for improving tenderness and quality attributes of nonconforming products. According to FAO, in the year 2015, the world food consumption was $41.3 \mathrm{~kg}$ per capita, and it has been projected for the coming 2030 to be $45.3 \mathrm{~kg}$ per capita
(Kerry et al., 2002). Depend on the increased interest in meat consumption that forces the meat industry to provide consistent supplies of high-quality meat. The demand for high-quality meat is important for consumer's choice (Mullen et al., 2017), it has a high value of eating quality according to the meat flavour, juiciness and tenderness, which has main attributes that influence the sensory enjoyment of meat (Grunert et al., 2004; Aaslyng and Meinert, 2017; Picard and Gagaoua, 2017). Tenderness has been shown to have the largest role in consumer purchasing decisions (Mennecke et al., 2007) and in particular repeat buying (Miller et al., 2001).

The tenderness of the meat is affected by both preslaughter and post-slaughter factors. Pre slaughter factors include species, breed, age, sex, feeding and management, genetic influence and stress conditions. The crucial structural components are the myofibrils and the connective tissue in the meat which provide support for muscle at different hierarchies (Lepetit, 2008). Meat myofibrils are composed of actin and myosin, and connective tissue is composed of collagen and elastin (Bailey and Light, 1989). The relative proportion of these two components determines the structural composition of a meat cut and therefore influences its 
tenderness. The second component contributing to meat toughness is post-slaughter factors that influence meat tenderness including post-mortem glycolysis, postmortem shortening, and conditioning, processing and cooking methods, in the contractile apparatus of the muscle (the sarcomere). The sarcomere undergoes a shortening phase during the development of rigor mortis. The toughness caused by muscle shortening is primarily influenced by processing conditions (Geesink et al., 2006; Gómez et al., 2020).

There are different ways to improve the quality of meat, such as temperature treatment of carcass, electrical stimulation, suspension method and adding tenderizer (Koohmaraie et al., 2002; Hwang et al., 2003). As many studies recommended that among this method using enzyme is the most valuable and effective (Zahir et al., 2019; Harahap et al., 2020). Among several enzymes, bromelain is specifically useful and has an industrial prospect in tenderization. Bromelain is a crude aqueous mixture of proteolytic enzyme which is found in the tissues of the plant family Bromeliaceae of pineapple (Ananas comosus L. Merryl) in the different parts. The discarded parts of the pineapple tree such as cores, peels and leaves contain bromelain in relatively smaller quantities to stems and fruits (Sriwatanapongse et al., 2000; Maurer, 2001; Hebbar et al., 2012). The enzyme extracted from the stem is called stem bromelain and from the fruit is called fruit bromelain (EC 3.4.22.32, formerly EC 3.4.22.4), (Babu et al., 2008). Numerous documented research point to bromelain enzyme as the most used in meat tenderization (Hebbar et al., 2008; Chaurasiya et al., 2015), such as beef meat (Ketnawa et al., 2012), mutton, chicken meat (Koide et al., 2010) and pork meat (Ieowsakulrat et al., 2011). Its closely related proteinases have also demonstrated in vitro and in vivo, anti edematous, antiinflammatory, antithrombotic (Bhui et al., 2009; Kwatra, 2019), fibrinolytic activities and has potential as an anticancer agent. However, very few studies focus on the extraction of bromelain from plant wastes and its application in tenderization (Nanda et al., 2020).

Therefore, the present work recognizes the toughness of meat as one of the quality problems in the meat industry that decrease palatability and customer acceptability of meat in turn influencing the meat marketing system. The objective of this study is to improve the quality of meat using the natural proteolytic enzyme bromelain. At the same time, the work strongly focusses on the aspect of agricultural waste utilization. Considerable biomass of the pineapple tree is wasted after fruit harvest and fruit consumption. This waste is presently not used for any organized process. Therefore, extraction of bromelain from such material could be an economically viable and environmentally friendly operation to finally use the enzyme for different applications including tenderization of meat.

\section{Materials and methods}

\subsection{Chemicals}

Sodium dodecyl sulfate (SDS) and tris base were procured from Himedia Mumbai. Ethylene diamine tetra acetic acid (EDTA), bovine serum albumin (BSA), Betamercaptoethanol $(\beta \mathrm{ME})$, Coomassie Brilliant Blue G250, polyethylene glycol (PEG), electrophoresis reagents, magnesium sulfate and sodium phosphate, sodium carbonate, sodium potassium tartarate, sodium hydroxide, copper sulphate and commercial bromelain enzyme were purchased from Sigma Aldrich Pvt Ltd, Bengaluru, India. The pineapple (Ananas comosus) peel was obtained from the local fruit market and adult goat thigh muscle was purchased from the local supermarket. All chemicals were of analytical grade.

\subsection{Sample collection}

A total of $200 \mathrm{~g}$ of fresh pineapple peels were collected from the local market. The samples were washed and rinsed repeatedly with tap water and distilled water to remove any dust particles. The peels were then refrigerated till experimentation. $300 \mathrm{~g}$ of boneless raw goat thigh muscle was purchased and refrigerated for experiments.

\subsection{Bromelain extraction}

Bromelain proteolytic enzyme was extracted by a method described by Chaurasiya and Hebbar (2013). The washed peels were cut into small pieces, which were weighed and ground by grinder-mixer using $0.1 \mathrm{M}$ sodium phosphate buffer at a $\mathrm{pH}$ 7.0. The ground pulp was filtered with a cleaned cotton cloth and centrifuged at $7000 \mathrm{rpm}$ for $20 \mathrm{mins}$ at $10^{\circ} \mathrm{C}$.

\subsection{Purification of bromelain using ammonium sulphate precipitation}

Precipitation of protein was performed according to the method described by Chaurasiya et al. (2015). Ammonium sulphate was added in small quantities to crude extract which was maintained at $5-8^{\circ} \mathrm{C}$ until the desired saturation was reached. After the addition of ammonium sulphate, the protein solution was continuously stirred for 30 mins while maintaining low temperature to allow precipitation. The samples were centrifuged for $20 \mathrm{mins}$ at $11000 \times \mathrm{g}$ and $4^{\circ} \mathrm{C}$. The supernatant was discarded. The pellets were collected and kept in an inverted position for 15 mins to remove 
extra liquid containing salt and contaminants. The pellet was then dissolved in $0.01 \mathrm{M}$ phosphate buffer $(\mathrm{pH} 7.0)$ and this sample was used to measure the protein content in the purified sample.

\subsection{Treatment of meat samples by bromelain}

The experiments were carried out in triplicates using 15 pieces of $3 \times 3 \times 3 \mathrm{~mm}$ of goat thigh muscles segregated into 5 groups [ 1 control and 4 bromelain treated $(1 \mathrm{mg} /$ $\mathrm{mL}$ of bromelain solution)] in the same concentration with different time durations T1-30 mins, T2-60 mins, T3-90 mins and T4-120 mins, but the control sample was marinated using distilled water. Prior to marinating each sample was weighed to determine the amount of marination solution needed, then after marinating the sample were dried on a paper towel to remove the residual solution. Thus, one sample from each treatment was used for the analyses of cooking loss, water holding capacity and $\mathrm{pH}$ after marination. Therefore, all analyses for the first trial were completed in two days. The next procedure SDS-PAGE electrophoresis had been continued and the analyses completed in four days.

\subsection{Determination of $\mathrm{pH}$}

The $\mathrm{pH}$ was determined by the method reported by Wardy, Saalia, Steiner-Asiedu, Budu, and Sefa-Dedeh (2009). The measurement was carried out by dipping a calibrated pH-meter probe into a mixture of homogenized meat and distilled water. All measurements were performed at room temperature $\left(20^{\circ} \mathrm{C}\right)$.

\subsection{Cooking loss}

The marinated adult goat meat was weighed and packed into thin layered polyethylene bags which were labelled according to the treatment and broiled for 20 mins at a temperature of $100^{\circ} \mathrm{C}$ in a water bath. After 20 mins, the released water is manually separated from the meat samples. The samples are allowed to return to room temperature $\left(27^{\circ} \mathrm{C}\right)$ for 30 mins (Mahendrakar et al., 1988). Samples were measured before and after cooking to determine the cooking loss. Cooking loss was determined by loss of meat after cooking as per equation 1 :

Cooking loss $=\frac{\text { Weight of raw sample }- \text { weight of cooked sample }}{\text { weight of raw meat }} \times 100$

\subsection{Water holding capacity (WHC)}

According to the method by Chaurasiya et al. (2015), $12 \mathrm{~mL}$ of $0.6 \mathrm{M} \mathrm{NaCl}$ was added to $8 \mathrm{~g}$ of ground meat. The mixture was then centrifuged at $5^{\circ} \mathrm{C}$, $1977 \times g$ for 15 mins. The supernatant was poured into a measuring cylinder and the volume was recorded. The WHC was calculated as the following equation 2 and expressed in percentage (\%):

$\mathrm{WHC}(\%)=\frac{\text { volumeof } \mathrm{NaCl} \text { beforecentrifuge }- \text { volume of } \mathrm{NaClaftercentrifuge}}{\text { volumeof } \mathrm{NaCl} \text { before centrifuge }} \times 100$

\subsection{Electrophoresis}

The procedure of electrophoresis was carried out according to the method in Laemmli (1970). A total of 2 $\mathrm{g}$ of the sample subjected to different treatment conditions were mixed with $18 \mathrm{~mL} 5 \%$ (w/v) SDS solution $\left(85^{\circ} \mathrm{C}\right)$. The mixture was homogenized to dissolve the sample. The homogenized sample was incubated in the water bath at $85^{\circ} \mathrm{C}$ for 60 mins and subsequently centrifuged at room temperature $8000 \times g$ for 5 mins, to remove the undissolved debris. The sample buffer containing $0.5 \mathrm{M}$ Tris-HCL, $\mathrm{pH}$ of 6.8 containing $4 \%$ SDS, $20 \%$ glycerol and 10\% BME mixed with the supernatant at 1:1 ratio and boiled for 3 mins. The $20 \mu \mathrm{g}$ protein sample was loaded into polyacrylamide gel which has $10 \%$ running and $4 \%$ stacking gels and then subject to the electrophoresis set at a constant current of $15 \mathrm{~mA}$ per gel using a Mini Protean Tetra Cell Unit. After the sample is run in an electrophoresis gel, the gel was stained by staining solution containing Coomassie Brilliant Blue R-250 0.02\% (w/v) in 50\% (v/v) methanol, and $7.5 \%(\mathrm{v} / \mathrm{v})$ acetic acid overnight. Then the protein pattern was visualized after distaining the gel until a clear background was achieved.

\subsection{Protein content}

The protein content was determined by measurement of the absorbance at $280 \mathrm{~nm}$ using BSA as standard (Layne, 1957). The sample analysis is performed against a respective blank solution. The protein concentration readings were recorded in triplicates and an average value is used for the calculation.

\subsection{Statistical analysis}

The obtained data were statistically analyzed with the SPSS program for Windows (SPSS version 11.5, SPSS Inc., Chicago, IL, USA). Duncan's multiple range test was used to compare the difference between means. The accepted level of significance for all comparisons was $p<0.05$. Experiments were conducted in triplicates.

\section{Results and discussions}

\subsection{Effect of extraction medium of protein recovery}

Extraction of protein from pineapple was performed using different extraction media. Table 1 summarises that the extraction of protein using sodium phosphate buffer was higher when compared to extraction using distilled water for all three samples. Based on the results, sodium phosphate buffer and partially ripe fruit were selected for further studies. 
Table 1. Effect of different extraction medium on protein content

\begin{tabular}{lcc}
\hline Treatment & $\begin{array}{c}\text { Protein }(\mathrm{mg} / \mathrm{mL}) \text { using } \\
\text { buffer }\end{array}$ & $\begin{array}{c}\text { Protein }(\mathrm{mg} / \mathrm{mL}) \text { using } \\
\text { distilled water }\end{array}$ \\
\hline Ripe & $12.15 \pm 1.25$ & $11.45 \pm 0.65$ \\
Partially Ripe & $17.95 \pm 0.82$ & $10.3 \pm 0.74$ \\
Raw & $16.92 \pm 0.71$ & $11.42 \pm 0.79$ \\
\hline
\end{tabular}

Values are expressed as mean $\pm \mathrm{SD}, \mathrm{n}=3$.

\subsection{Purification using ammonium sulphate precipitation}

Ammonium sulphate is the most widely used precipitation agent because of high solubility, low cost, no extreme $\mathrm{pH}$ change and no denaturation of proteins. Preliminary studies were carried out $\left(5-8^{\circ} \mathrm{C}\right)$ to find out the saturation level for ammonium sulphate and it was found to be $70 \%$. Table 2 shows the spectrophotometry $(660 \mathrm{~nm})$ reading of the protein content. Precipitation in the case of a buffer as extraction medium is significantly $(\mathrm{P}>0.05)$ higher than the extraction of bromelain using distilled water, therefore the buffer was selected for further studies.

Table 2. Effect of extraction medium on precipitation of protein

\begin{tabular}{cc}
\hline Extraction medium & Protein concentration $(\mathrm{mg} / \mathrm{mL})$ \\
\hline Buffer & $12.25 \pm 0.08$ \\
Distilled water & $9.56 \pm 0.07$
\end{tabular}

Values are expressed as mean $\pm \mathrm{SD}, \mathrm{n}=3$.

\subsection{Protein content}

Marinating meat sample with bromelain is important to get the estimated amount of protein available in the sample and to proceed with other quality parameters like cooking loss, $\mathrm{pH}$ and moisture content. The margination samples are shown in Figure 1. The results of the Lowry method of protein estimation was tabulated in Table 3. It is seen that the protein content significantly $(p<0.05)$ increased as the ageing duration increased. This method helps in evaluating the tenderness of meat by measuring the degradation of the myofibrillar proteins found in the meat by bromelain. The colour change is shown in Figure 2. The reaction that occurs in Lowry assay is the binding of copper to the nitrogen in the peptide and, the phosphomolybdic tungstic acid in the Folin-Ciocalteau reagent gets reduced to hetero polymolybdenum blue by the copper catalysed oxidation of aromatic amino acids in the peptide, in alkaline condition. The result expresses that the untreated meat i.e. control shows significantly lowered protein content $(1.22 \mathrm{mg} / \mathrm{mL})$ than the treated samples, $\mathrm{T} 1=1.73, \mathrm{~T} 2=2.09, \mathrm{~T} 3=2.11$ and $\mathrm{T} 4=2.18$ $\mathrm{mg} / \mathrm{mL}$. The ageing duration was $30,60,90$ and 120 mins respectively, the control had been marinated by distilled water for 120 mins. The cooking loss and $\mathrm{pH}$ values also decrease with increasing treatment time, signifying that extended action of bromelain improves the quality of the meat.
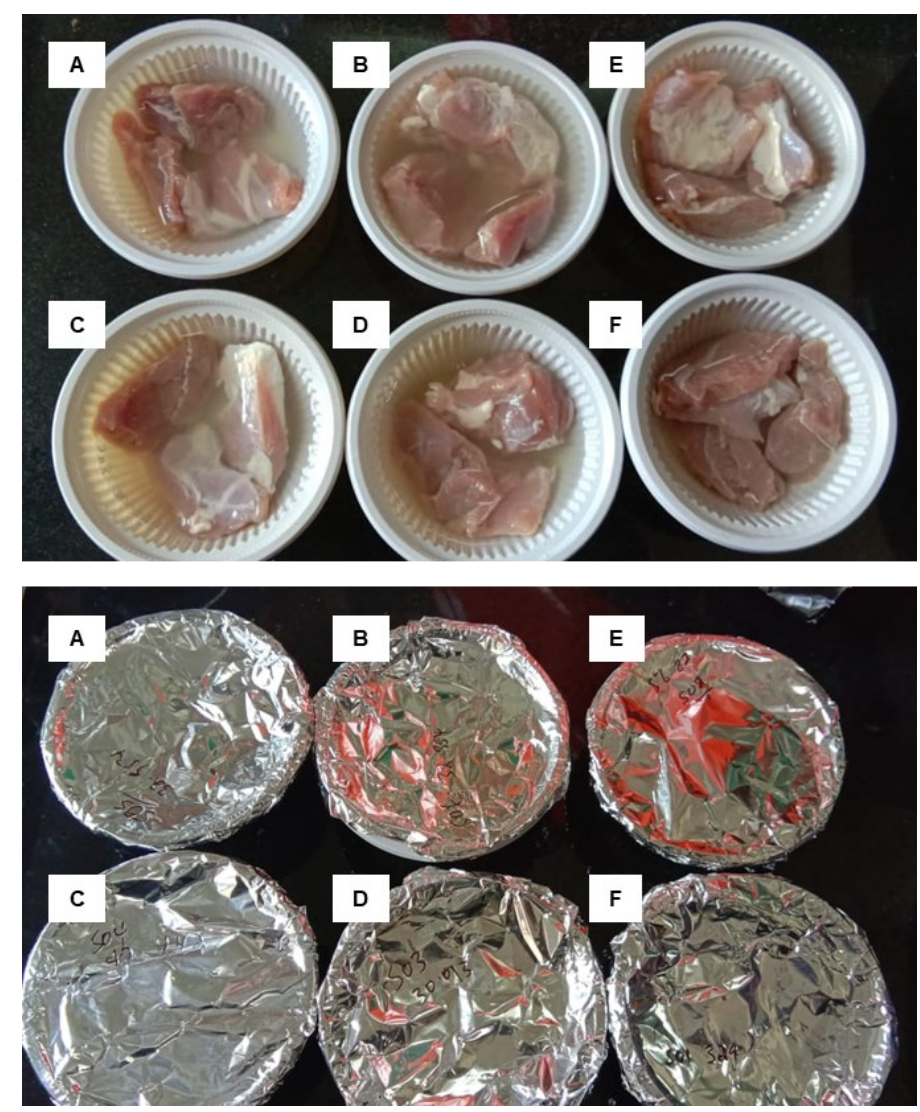

Figure 1. Experimental samples for meat tenderization using bromelain; A: Treated for 30 mins, B: Treated for 60 mins, C: Treated for 90 mins, D: Treated for $120 \mathrm{mins}$, E: Control (meat with water) and F: Only meat.

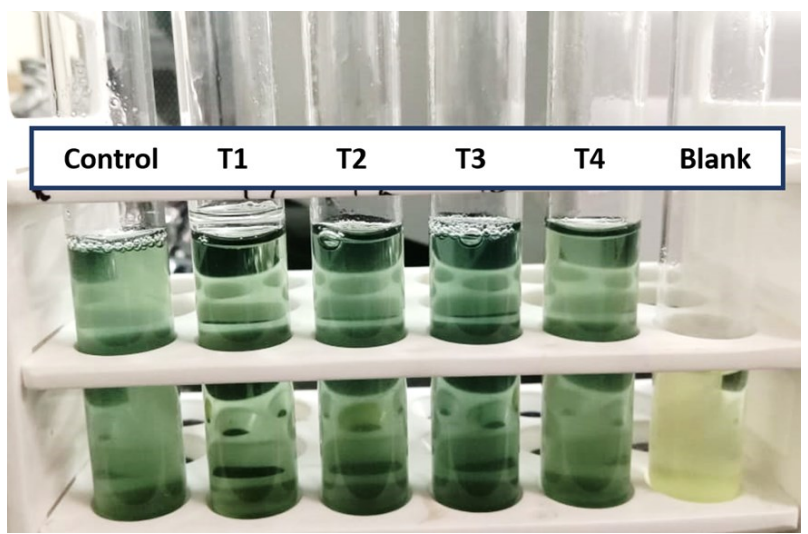

Figure 2. Change in colour due to different treatment time during Lowry assay (Control $=$ Untreated sample, $\mathrm{T} 1=$ treated for 30 mins, T2 = treated for 60 mins, T3 = treated for 90 mins and $\mathrm{T} 4=$ treated for $120 \mathrm{mins}$ ).

\subsection{Cooking loss}

Cooking loss of the treated and untreated samples was measured by boiling the samples at $95^{\circ} \mathrm{C}$ using aluminium pouch (Figure 3 ) and the values are shown in Table 3. A decrease in cooking loss was observed in samples treated with bromelain. Cooked meats have suffered significant changes, one of the most important 
being weight loss, due to juice and fat losses.

Table 3. Effect of time on soluble protein concentration, cooking loss and $\mathrm{pH}$

\begin{tabular}{cccc}
\hline Treatment & Protein Concentration & $\mathrm{pH}$ value & Cooking loss \\
\hline Blank & 0 & - & - \\
Control & $1.22 \pm 0.01$ & $6.2 \pm 0.04$ & $53.23 \%$ \\
T1: 30 mins & $1.73 \pm 0.11$ & $5.82 \pm 0.09$ & $25.71 \%$ \\
T2: 60 mins & $2.09 \pm 0.08$ & $5.61 \pm 0.08$ & $20.59 \%$ \\
T3: 90 mins & $2.11 \pm 0.05$ & $5.53 \pm 0.02$ & $18.75 \%$ \\
T4: 120 mins & $2.18 \pm 0.02$ & $5.11 \pm 0.01$ & $11.76 \%$ \\
\hline
\end{tabular}

Values are expressed as mean $\pm \mathrm{SD}, \mathrm{n}=3$. Control: without enzyme

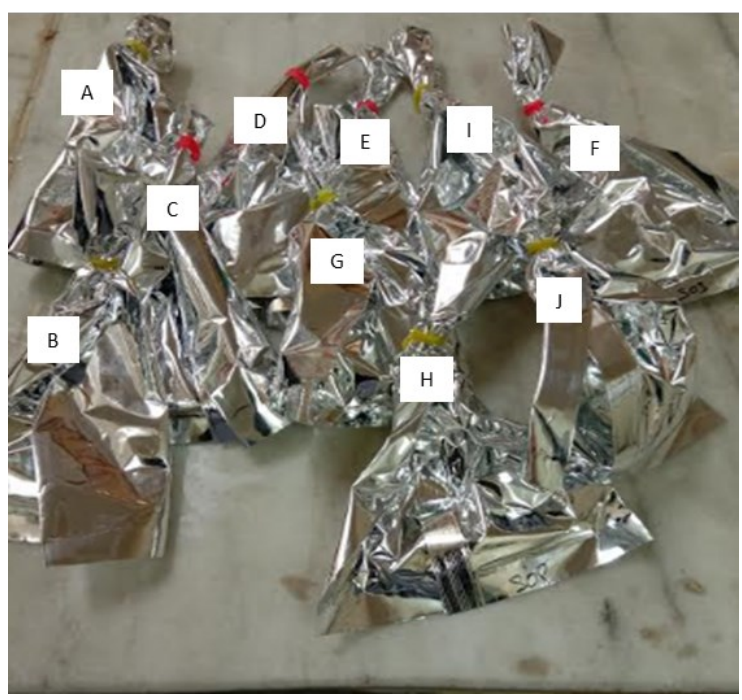

Figure 3. Treated and untreated cooked meat samples for checking the loss on cooking; A: Control (with water), B: Only meat, C: Treated for 30 mins, D: Treated for 60 mins, E: Treated for 90 mins, F: Treated for 120 mins, G: Treated for 30 mins (duplicate), H: Treated for 60 mins (duplicate), I: Treated for 90 mins (duplicate), and J: Treated for 120 mins (duplicate)

\section{$3.5 \mathrm{pH}$ of meat}

The $\mathrm{pH}$ is an important parameter in bromelain marinated meat which has a direct effect on shelf life, colour and quality of the meat and also it has a major influence on other physio-chemical and quality properties such as WHC, tenderness and juiciness of meat and meat product. $\mathrm{pH}$ change in meat is due to post -mortem metabolism and also due to the application of added substances to the meat during processing (Goli et al., 2007). The tenderization of the adult goat meat marinated with bromelain enzyme changed the $\mathrm{pH}$ value of meat. $\mathrm{pH}$ values were dependent on the bromelain concentration applied and ageing duration of marinating.

From Table 3, the result show that the $\mathrm{pH}$ of treated meat samples decreased as compared to the control sample. The lower $\mathrm{pH}$ of bromelain was probably the reason for the lowered $\mathrm{pH}$ of the treated samples; it might have resulted due to releasing of amino acids from enzyme-treated meat that can reduce the $\mathrm{pH}$ of the system. $\mathrm{pH}$ can keep the colour, aroma and texture of the meat if the meat significantly decreased with an increasing concentration may cause the meat to become more acidic and lose its natural quality characteristics and may damage the nutritive value and palatability. The $\mathrm{pH}$ values of enzyme-treated sample are $6.23-5.83$ at $0.5 \mathrm{mg} / \mathrm{mL}$ of bromelain concentration, $6.43-5.37$ at 1 $\mathrm{mg} / \mathrm{mL}$ of bromelain concentration and $6.27-5.13$ at 1.5 $\mathrm{mg} / \mathrm{mL}$ of bromelain concentration.

We can see that the $\mathrm{pH}$ change is not extreme - this is important to keep the natural quality of meat because $\mathrm{pH}$ has the ability to change the colour, aroma and texture of the meat. The results have been expressed for the same concentration of enzyme with a different ageing duration of marination (30, 60, 90 and 120 mins respectively).

\subsection{SDS-PAGE electrophoresis}

Electrophoresis is a method by which a complex mixture of proteins can be separated. Sodium dodecyl sulphate polyacrylamide gel electrophoresis (SDSPAGE) is a technique used to move charged molecules through a gel matrix by means of an electric current. This procedure is used to determine protein subunit composition, verify homogeneity of the protein sample, and purify proteins for use in other applications. The migration rate of the proteins during SDS-PAGE is determined by the pore size of the gel matrix and the charge, the size, and the shape of the protein.

\section{$\begin{array}{lllll}\text { T4 } & \text { T3 } & \text { T2 } & \text { T1 } & \text { Control }\end{array}$}

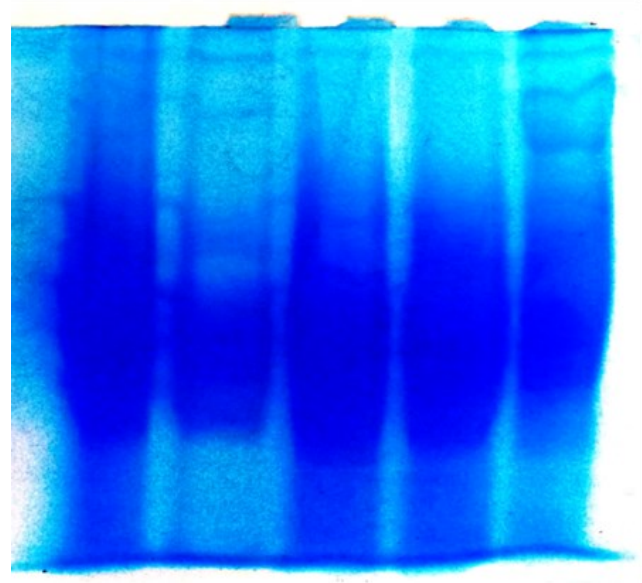

Figure 4. SDS-PAGE patterns of meat samples treated with same concentration of bromelain enzyme with different ageing duration of marinated meat sample. Control = Untreated sample, $\mathrm{T} 1=$ treated for $30 \mathrm{mins}, \mathrm{T} 2=$ Treated for 60 mins, $\mathrm{T} 3=$ Treated for 90 mins, $\mathrm{T} 4=$ Treated for 120 mins.

Figure 4 indicates that protein denaturation in the sample increased as the ageing duration increased. The 
control (untreated) has a heavier protein band than the treated samples because the movement of large molecules is slower on the gel matrix. Samples treated for 120 mins was more denatured than the other treated samples. Time treatment in the same concentration (1 $\mathrm{mg} / \mathrm{mL}$ ) was directly proportional to the protein denaturation. The protein denatured indicated that the meat samples were tenderized by the commercial bromelain enzyme. Therefore the effectiveness of the BE was confirmed as the result of estimation of protein content were correlated with other parameters, such as cooking loss, WHC and $\mathrm{pH}$ of meat.

\subsection{Water holding capacity (WHC)}

Water holding capacity of the meat is one of the quality parameters to evaluate the tenderness of meat and meat products, it is very important since many physical properties such as colour, texture and firmness are partially dependent on the WHC, as it directly affects yield and quality of the meat and it has a direct bearing on economic value. Water holding capacity can be defined as the ability of meat to retain the inherent water even under external pressure. The juiciness of the meat is mainly related to the WHC of meat or low intramuscular fat level. Myofibrillar shrinkage/swelling and movement of water from the myofilament space into the extracellular space causes a reduction in the WHC of meat. $\mathrm{NaCl}$ is commonly used to promote water retention and consequent swelling in myofibrils. The decrease of WHC was due to the action of bromelain in the denaturation of myofibrillar proteins which play a role in water retention. Besides, the decrease of $\mathrm{WHC}$ was due to the myofibrillar shrinkage as well as the movement of water from the myofilament space into the extracellular space (Sunantha and Saroat, 2011).

In this study, there was a significant reduction of WHC in all of the treated samples, especially when the concentration of bromelain increased $(p<0.05)$. The results show the decreases in WHC to be from $40.58 \%$ to $11.08 \%$. The lowest WHC values were observed in the

Table 4. Effect of different concentration of bromelain on WHC and $\mathrm{pH}$

\begin{tabular}{lcc}
\hline Treatment in different & \multicolumn{2}{c}{ Treated meat sample } \\
\cline { 2 - 3 } concentration of bromelain & WHC & $\mathrm{pH}$ value \\
\hline Control & $40.58 \%$ & $6.23 \pm 0.06$ \\
T1 & $30.25 \%$ & $5.83 \pm 0.6$ \\
T2 & $15.25 \%$ & $5.37 \pm 0.15$ \\
T3 & $11.08 \%$ & $5.13 \pm 0.06$ \\
\hline
\end{tabular}

Values are expressed as mean $\pm \mathrm{SD}, \mathrm{n}=3 . \mathrm{T} 1=0.5 \mathrm{mg} / \mathrm{mL}$ of bromelain concentration, $\mathrm{T} 2=1 \mathrm{mg} / \mathrm{mL}$ of bromelain concentration and $\mathrm{T} 3=1.5 \mathrm{mg} / \mathrm{mL}$ of bromelain concentration and the result indicated the treated sample significantly decreased $\mathrm{p}<0.05$.
T3 treated thigh muscle when compared with others (Table 4). The result showed that the higher WHC in the control sample and the reduction in all of the treated samples might be due to lower $\mathrm{pH}$, this drop in $\mathrm{pH}$ may be responsible for the overall reduction in protein reactive groups available for water holding and also due to probably the denaturation of myofibrillar proteins, which play a role in water retention. Bromelain could hydrolyse these proteins into small peptides or amino acids, which then could not function properly.

\section{Conclusion}

We have successfully demonstrated that treatment of goat meat with bromelain significantly increased ( $p$ $<0.05)$ its water holding capacity and the protein content. The SDS-PAGE result showed that the hydrolysis of myofibrillar meat protein was enhanced. Increasing the duration makes the meat more susceptible to the catalysis by bromelain leading to the meat producing juice and become more palatable. $\mathrm{pH}$ increase was insignificant which is important for keeping the quality characteristics of meat such as colour, aroma and texture. Bromelain concentration of $1 \mathrm{mg} / \mathrm{mL}$ to $1.5 \mathrm{mg} / \mathrm{mL}$ and ageing duration up to 120 minutes is suggested for tenderization without compromising food quality. Besides the positive effect on food characteristics, two other important findings are significant. The first is the utilization of peel of pineapple for the extraction of bromelain which has an advantage by changing this waste product (peels) into valuable product. Further, this reduces environmental waste and also raises the economic value of the crop for farmers. The second important contribution is that distilled water can be used to effectively extract crude protein from peels and to precipitate it by ammonium sulphate as effectively as buffer $(\mathrm{p}>0.05)$. This indicates the possibility of avoiding purchase of buffer salts in large scale production to reduce costs. We therefore conclude that this technology for the utilization of easily and cheaply available pineapple can be exploited at the industrial or household level for tenderization of tough meat.

\section{Conflict of interest}

The authors declare no conflict of interest.

\section{References}

Aaslyng, M.D. and Meinert, L. (2017). Meat flavour in pork and beef-From animal to meal. Meat Science, 132, 112-117. https://doi.org/10.1016/ j.meatsci.2017.04.012

Babu, B.R., Rastogi, N. and Raghavarao, K. (2008). Liquid-liquid extraction of bromelain and 
polyphenol oxidase using aqueous two-phase system. Chemical Engineering and Processing: Process Intensification, 47(1), 83-89. https:// doi.org/10.1016/j.cep.2007.08.006

Bailey, A.J. and Light, N.D. (1989). Connective tissue in meat and meat products. London: Elsevier Science Publishers.

Becker, T. (2000). Consumer perception of fresh meat quality: a framework for analysis. British Food Journal, 2(3), 158-176. https:// doi.org/10.1108/00070700010371707

Bhui, K., Prasad, S., George, J. and Shukla, Y. (2009). Bromelain inhibits COX-2 expression by blocking the activation of MAPK regulated NF-kappa B against skin tumor-initiation triggering mitochondrial death pathway. Cancer Letters, 282 (2), 167-176. https://doi.org/10.1016/ j.canlet.2009.03.003

Chaurasiya, R.S. and Hebbar, H.U. (2013). Extraction of bromelain from pineapple core and purification by RME and precipitation methods. Separation and Purification Technology, 111, 90-97. https:// doi.org/10.1016/j.seppur.2013.03.029

Chaurasiya, R.S., Sakhare, P., Bhaskar, N. and Hebbar, H.U. (2015). Efficacy of reverse micellar extracted fruit bromelain in meat tenderization. Journal of Food Science and Technology, 52(6), 3870-3880. https://doi.org/10.1007/s13197-014-1454-z

Geesink, G., Kuchay, S., Chishti, A. and Koohmaraie, M. (2006). $\mu$-Calpain is essential for postmortem proteolysis of muscle proteins. Journal of Animal Science, 84(10), 2834-2840. https://doi.org/10.2527/ jas.2006-122

Glitsch, K. (2000). Consumer perceptions of fresh meat quality: cross-national comparison. British Food Journal, 102(3), 177-194. https:// doi.org/10.1108/00070700010332278

Goli, T., Abi Nakhoul, P., Zakhia-Rozis, N., Trystram, G. and Bohuon, P. (2007). Chemical equilibrium of minced turkey meat in organic acid solutions. Meat Science, 75(2), 308-314. https://doi.org/10.1016/ j.meatsci.2006.07.016

Gómez, I., Janardhanan, R., Ibañez, F.C. and Beriain, M. J. (2020). The Effects of processing and preservation technologies on meat quality: sensory and nutritional aspects. Foods, 9(10), 1416. https://doi.org/10.3390/ foods 9101416

Grunert, K.G., Bredahl, L. and Brunsø, K. (2004). Consumer perception of meat quality and implications for product development in the meat sector-a review. Meat Science, 66(2), 259-272. https://doi.org/10.1016/S0309-1740(03)00130-X
Harahap, N.A., Satyantini, W.H. and Sudarno. (2020). Effect of enzyme papain against natural flavor of raw meat waste laundering surimi, IOP Conference Series: Earth and Environmental Science, 441(1), 012154 . https://doi.org/10.1088/1755$1315 / 441 / 1 / 012154$

Hebbar, H.U., Sumana, B. and Raghavarao, K. (2008). Use of reverse micellar systems for the extraction and purification of bromelain from pineapple wastes. Bioresource Technology, 99(11), 4896-4902. https:// doi.org/10.1016/j.biortech.2007.09.038

Hebbar, U.H., Sumana, B., Hemavathi, A. and Raghavarao, K. (2012). Separation and purification of bromelain by reverse micellar extraction coupled ultrafiltration and comparative studies with other methods. Food and Bioprocess Technology, 5(3), 1010-1018. https://doi.org/10.1007/s11947-010-0395 $-4$

Hwang, I., Devine, C. and Hopkins, D. (2003). The biochemical and physical effects of electrical stimulation on beef and sheep meat tenderness. Meat Science, 65(2), 677-691. https://doi.org/10.1016/ S0309-1740(02)00271-1

Ieowsakulrat, S., Theerasamran, P., Chokpitinun, C. and Pinitglang, S. (2011). Tenderisation of pork steak with fruit bromelain from pineapple monitored by sensory evaluation and texturometer. Journal of Agricultural Science, 42(2), 457-460.

Kerry, J.P., Kerry, J.F. and Ledward, D. (2002). Meat processing: Improving quality. USA: Woodhead Publishing. https://doi.org/10.1201/9781439823163

Ketnawa, S., Chaiwut, P. and Rawdkuen, S. (2012). Pineapple wastes: A potential source for bromelain extraction. Food and Bioproducts Processing, 90(3), 385-391. https://doi.org/10.1016/j.fbp.2011.12.006

Koide, A., Niwa, Y., Yamauchi, T., Ôba, K. and Sano, M. (2010). Effects of bromelain treatment on the concentration of free amino acids and tenderization of broiler breast meat. Japanese Journal of Food Chemistry and Safety, 17(1), 41-46.

Koohmaraie, M., Kent, M.P., Shackelford, S.D., Veiseth, E. and Wheeler, T.L. (2002). Meat tenderness and muscle growth: is there any relationship? Meat Science, 62(3), 345-352. https://doi.org/10.1016/ S0309-1740(02)00127-4

Kwatra, B. (2019) A review on potential properties and therapeutic applications of bromelain. World Journal of Pharmacy and Pharmaceutical Sciences, 8(11) 488-500

Laemmli, U.K. (1970). Cleavage of structural proteins during the assembly of the head of bacteriophage T4. Nature, 227(5259), 680-685. https:// 
doi.org/10.1038/227680a0

Layne, E. (1957). Spectrophotometric and turbidimetric methods for measuring proteins. In Colowick, P.S. and Kaplan, NO. (Eds.). pp. 447-454. Method in Enzymology. New York, USA: Academic Press Inc. https://doi.org/10.1016/S0076-6879(57)03413-8

Lepetit, J. (2008). Collagen contribution to meat toughness: Theoretical aspects. Meat Science, 80(4), 960-967.

https://doi.org/10.1016/ j.meatsci.2008.06.016

Mahendrakar, N., Khabade, V. and Dani, N. (1988). Studies on the effect of fattening on carcass characteristics and quality of meat fron Bannur lambs. Journal of food Science and Technology, 25 (4), 228-231.

Maurer, H. (2001). Bromelain: biochemistry, pharmacology and medical use. Cellular and Molecular Life Sciences CMLS, 58(9), 1234-1245. https://doi.org/10.1007/PL00000936

Mennecke, B.E., Townsend, A.M., Hayes, D.J. and Lonergan, S.M. (2007). A study of the factors that influence consumer attitudes toward beef products using the conjoint market analysis tool. Journal of Animal Science, 85(10), 2639-2659. https:// doi.org/10.2527/jas.2006-495

Miller, M.F., Carr, M., Ramsey, C., Crockett, K. and Hoover, L. (2001). Consumer thresholds for establishing the value of beef tenderness. Journal of Animal Science, 79(12), 3062-3068. https:// doi.org/10.2527/2001.79123062x

Mullen, A.M., Álvarez, C., Zeugolis, D.I., Henchion, M., O'Neill, E. and Drummond, L. (2017). Alternative uses for co-products: Harnessing the potential of valuable compounds from meat processing chains. Meat Science, 132, 90-98. https://doi.org/10.1016/ j.meatsci.2017.04.243

Nanda, R.F., Rini, B., Syukri, D., Thu, N.N.A. and Kasim, A. (2020). A review: application of bromelain enzymes in animal food products. Andalasian International Journal of Agricultural and Natural Sciences, 1(1) 33-44. https:// doi.org/10.25077/aijans.v1.i01.33-44.2020

Picard, B. and Gagaoua, M. (2017). Proteomic investigations of beef tenderness. Proteomics in Food Science: From Farm to Fork, p. 177-197. USA: Academic Press. https://doi.org/10.1016/B978-0-12804007-2.00011-4

Sriwatanapongse, A., Balaban, M. and Teixeira, A. (2000). Thermal inactivation kinetics of bromelain in pineapple juice. Transactions of the ASAE, 43(6), 1703. https://doi.org/10.13031/2013.3071
Sunantha, K. and Saroat, R. (2011). Application of bromelain extract for muscle foods tenderization. Food and Nutrition Sciences, 2, 393 - 401.

Wardy, W., Saalia, F.K., Steiner-Asiedu, M., Budu, A.S. and Sefa-Dedeh, S. (2009). A comparison of some physical, chemical and sensory attributes of three pineapple (Ananas comosus) varieties grown in Ghana. African Journal of Food Science, 3(4), 094099.

Zahir, H.G., Saleh, H.H. and Mahmud, A.B. (2019) Tenderization Efficiency of Cucumis Extract (Cucumis Trigonus Rox-b)Compared with Papain enzyme on the Aged Bull Meat by Injection Method. Al-Anbar Journal of Veterinary Sciences, 12(1), 125141. https://doi.org/10.37940/AJVS.2019.12.1.14 